\title{
Ichthyofauna diversity of Taperoá II reservoir, semi-arid region of Paraíba, Brazil
}

\author{
Montenegro, AKA. ${ }^{a}{ }^{*}$, Torelli, JER. $^{a}$, Crispim, MC. ${ }^{a}$, Hernández, MIM. ${ }^{b}$ and Medeiros, AMA. ${ }^{c}$ \\ ${ }^{a}$ Departamento de Sistematica e Ecologia - DSE, Centro de Ciências Exatas e da Natureza - CCEN, \\ Universidade Federal da Paraíba - UFPB, Castelo Branco, CEP 58000-000, João Pessoa, PB, Brazil

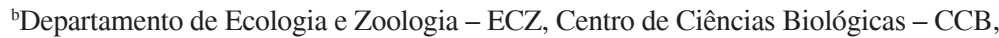 \\ Universidade Federal de Santa Catarina - UFSC, Campus Universitário, Trindade, CEP 88040-900, Florianópolis, SC, Brazil \\ 'Universidade Estadual da Paraíba - UEPB, Rua Baraúnas, 351, Bairro Universitário, \\ CEP 58429-500, Campina Grande, PB, Brazil \\ *e-mail: biokarla_21@ hotmail.com
}

Received January 13, 2011 Accepted April 4, 2011 - Distributed February 29, 2012

(With 5 figures)

\begin{abstract}
To determine the fish species present in Taperoá II Reservoir, and their relevance to the local economy, this research aimed to evaluate the composition, abundance, degree of dominance and constancy of species, along with diversity, richness, evenness and similarity indices in a tropical semi-arid fish assemblage, during one year. Six 24 hour-long samplings were carried out between October 2005 and October 2006 using cast, seine and gillnets. The 889 collected individuals belonged to 11 species from 9 families. Temporal variation was observed in the capture frequency of different species, and a significant negative correlation between precipitation and number of individuals was also observed. Among the recorded families, Characidae showed a higher frequency of occurrence (38.4\%), mostly due to Astyanax bimaculatus (Linnaeus, 1758) and A. fasciatus (Cuvier, 1819). Eight species were categorised as constant, two as accessory and one as accidental. Diversity index values were intermediate with low fluctuation throughout the study period, and no correlation with precipitation or water volume. However, the greatest diversity value was recorded in March 2006, when the peak of the precipitation was recorded. Evenness values showed a similar trend to the diversity index.
\end{abstract}

Keywords: reservoir, ecology, community, temporal variation.

\section{Diversidade da ictiofauna do açude Taperoá II, semiárido paraibano, Brasil}

\section{Resumo}

Para determinar as espécies de peixe presentes no Açude Taperoá II e sua relevância para a economia local, objetivou-se determinar a composição, a abundância, a dominância e a constância de espécies da ictiofauna, bem como os índices de diversidade (H'), riqueza, equitabilidade e similaridade de espécies ao longo de um ano. Foram realizadas seis coletas ao longo de 24 horas, de outubro de 2005 a outubro de 2006, utilizando-se tarrafas, redes de espera e arrasto. Foram coletados 889 indivíduos, identificados em 11 táxons específicos, distribuídos em nove famílias. A abundância das diferentes espécies variou temporalmente, com correlação negativa significativa entre a precipitação e o número de indivíduos. Dentre as famílias identificadas, Characidae apresentou a maior frequência de ocorrência (38,5\%), representada pelas espécies Astyanax bimaculatus (Linnaeus, 1758) e A. fasciatus (Cuvier, 1819). Oito espécies foram consideradas constantes, duas acessórias e uma acidental. O índice de diversidade apresentou valores entre 2,11 e 2,80, e não apresentou correlação com a precipitação e o volume do açude. Entretanto, o índice de diversidade mais elevado foi registrado no mês de março de 2006, pico do período chuvoso. Os valores da equitabilidade comportaram-se de forma semelhante aos do índice de diversidade.

Palavras-chave: reservatório, ecologia, comunidade, variação temporal. 


\section{Introduction}

The lack of knowledge on the composition of the freshwater ichthyofauna of the Northeastern region of Brazil is highly evident. In fact, species distribution lists and reports on the Neotropical freshwater ichthyofauna often show distribution gaps for many fish species within this region, due to the scarcity of fish records in the area (Santos, 2005).

Within Brazilian northeastern micro-regions, the semiarid is highly limited in its hydrologic resources, particularly due to typical low precipitation and high evaporation rates, which increase the eutrophication processes of water bodies and constrain water accumulation in these environments. Water levels vary from total absence (dry periods) to great discharges (rainy season) in most semiarid aquatic environments.

According to Rosa et al. (2003), the ichthyofauna of the Caatinga region consists of typical species from several Neotropical groups, with the exception of annual fishes (Rivulidae), showing a substantially small diversity when compared to other Brazilian environments. These fish assemblages are common in freshwater basins of the Northeastern Brazilian region, partially draining from, or encompassing entire environments located in the Caatinga. Consequently, due to these patterns, a regional ichthyofauna characterisation is precluded.

The hydrologic cycle initiates during the rainy period, when aquatic environments accumulate water. Following water evaporation in the dry season, variations in the trophic state take place over time. These events play an important role in the organisation and functioning of aquatic ecosystems, inducing adaptive surviving strategies by species, which enhance intra and inter-specific competition, alterations in the community structure, and alterations in the availability of food resources.

Teixeira et al. (2005) stated that investigating biodiversity, particularly fish assemblage structure and its variation patterns through space and time, is relevant to assess environmental quality, given that fishes occupy different positions in aquatic food webs. According to Wootton (1990), the communities from a specific environment can be analysed according to various aspects, including diversity, richness and evenness parameters.

To determine the fish species present in Taperoá II Reservoir, and their relevance to the local economy, this research aimed to describe the species composition, abundance, degree of dominance and constancy of species, species diversity index, species richness, evenness and similarity of the ichthyofauna of this reservoir throughout a one year period. Since little research on the fish diversity of semi-arid environments in the Northeastern region have been accomplished, this study also aims to contribute to fish diversity knowledge in the region by testing the following hypotheses: 1) this environment has low diversity due to extreme hydrological conditions; 2) there are no seasonal differences among species, and 3) species do not show similar abundances.

\subsection{Study area}

Taperoá II Reservoir is located in the Taperoá River basin, in the central region of Paraíba State $\left(07^{\circ} 11^{\prime} 44^{\prime \prime} \mathrm{S}-07^{\circ} 13\right.$ ' 44" S and $36^{\circ} 52^{\prime} 03$ " W-36 50' 09" W) (Figure 1). It has a surface area of $4.6 \mathrm{~km}^{2}$, a maximum water accumulation capacity of $15,148,900 \mathrm{~m}^{3}$, a maximum depth of $5.7 \mathrm{~m}$ and a mean depth of $1.4 \mathrm{~m}$. The reservoir is mostly used to supply water to Taperoá city and neighbouring cities, eventually connecting to the intermittent Taperoá River.

The semi-arid region of Paraíba has two well-defined seasons, namely, the rainy season, lasting between three and four months, and the dry season, lasting for almost the rest of the year. The weather of this region is classified as BSh' (Köppen climate classification), which indicates a hot and dry semi-arid climate, with a rainy season during the summer and fall. This region has the lowest precipitation indexes of Brazil (i.e. $300 \mathrm{~mm}$ per year).

Sampling was carried out during the dry season of 2005 (October and December), rainy season of 2006 (March and June), and the dry season of 2006 (August and October) (http://www2.aesa.pb.gov.br/meteoro/chuvas. shtml) (Figure 2).

Water volume in the Taperoá II reservoir showed high fluctuations throughout the study period, varying from a minimum of $3.930 .838 \mathrm{~m}^{3}$ in December of 2005 to a maximum $15.148 .900 \mathrm{~m}^{3}$ in May, June and July of 2006 (overflow) (Paraíba, 1997). However, it did not dry completely during the study period (Figure 2).

\section{Material and Methods}

Six samplings were performed during a 24-hour period. Fish specimens were collected using the following fishing instruments: cast nets and seine nets $(15 \mathrm{~mm}$ mesh net between adjacent knots, nylon bags with $0.2 \mathrm{~mm}$ of net open, length and width of 5 and $2 \mathrm{~m}$, respectively) and gillnets (meshes of 15, 20, 25, 35 e $40 \mathrm{~mm}$, between adjacent knots, length and height of 20 and $2 \mathrm{~m}$, respectively).

Samples were collected in the deepest sector of the reservoir, near the dam, in the limnetic and shore zones, at four hours intervals, totalling six samples. During each interval gillnets and cast nets were used in the reservoir edges, 30 and 15 times, respectively, whereas the seine net was used 10 times, in the edges and in the limnetic zone of the reservoir.

\subsection{Ichthyofauna composition}

Specimens were preserved in the field in a $10 \%$ formalin solution and subsequently transferred to the Aquatic Ecology Laboratory/Departamento de Sistemática e Ecologia/Universidade Federal da Paraíba. Taxonomic identifications were based on Fowler (1954), Britski (1972), Britski et al. (1988), Vari (1991) and confirmed by a taxonomist (Prof. Dr. Ricardo Rosa). Voucher specimens were deposited in the Universidade Federal da Paraíba Ichthyologic Collection (UFPB catalogue numbers: 6175, 6176, 6177, 6178, 6179, 6180, 6181, 6182, 6183, 6184 and 6185). 


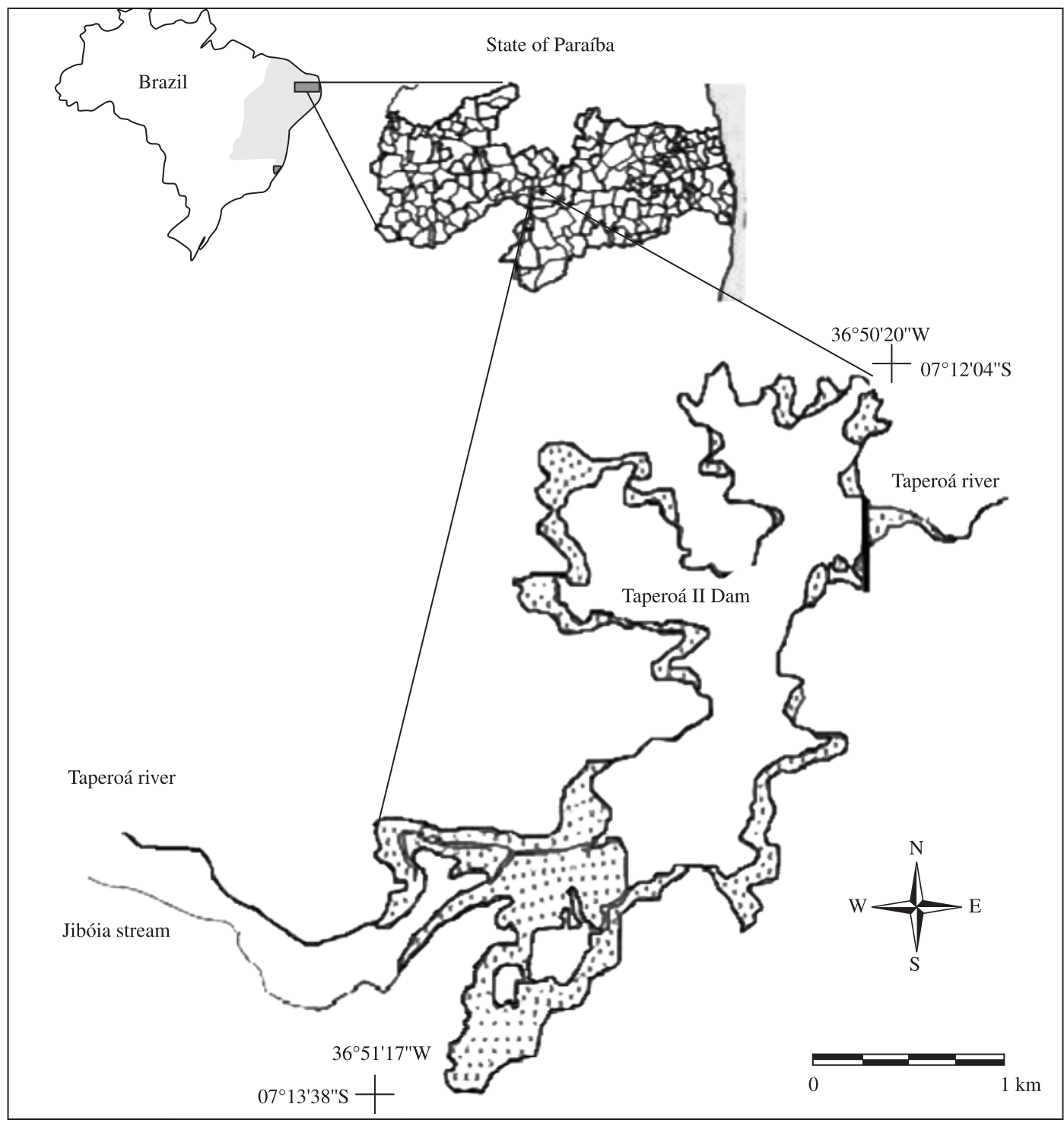

国 Aquatic vegetation

Figure 1. Taperoá II dam location in Taperoá, Paraíba, Brazil.

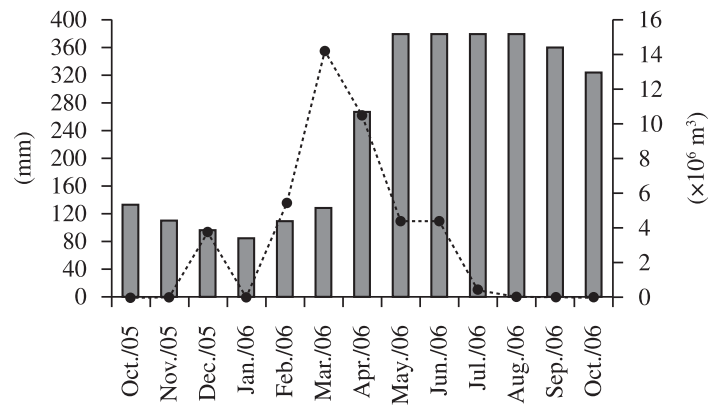

$\square$ Reservoir volume ..-.-. Rainfall

Figure 2. Pluviometric indexes (bars) in the Taperoá region and volume (lines) in the Taperoá II Reservoir during the study period (AESA, 2007).

\subsection{Abundance, dominance and constancy}

Abundance of fishes was determined following the total number of caught individuals of each species per sample. Spearman's correlation was used to test the variation in the abundance of different species through time.

Simpson's Dominance Index was employed according to McNaughton (1968) to determine the degree of dominance (D) among species. This estimate is an important means of determining the effects of the most abundant species on fish assemblage dynamics and on the overall biotic community.

The Constancy Index (C) (Dajoz, 1973) was employed to classify the constant species in the Taperoá II reservoir during the study period. This index determines which species remain in the assemblage for longer periods, therefore, being less affected by seasonal environmental variations. 


\subsection{Assemblage parameters and similarity}

Shannon's Index (H') (bits/ind) was employed as a diversity index per sample, and the resulting values were classified according to Pinto-Coelho (2000). Diversity Index and Camargo's evenness Index (E') were calculated using the Ecological Methodology software (Kenney and Krebs, 2000), respectively, based on Equation 1:

$$
H^{\prime}=-\sum_{\mathrm{i}=1}^{\mathrm{s}} \mathrm{p}_{\mathrm{i}}\left(\log _{2} \mathrm{p}_{\mathrm{i}}\right)
$$

where $\mathrm{p}_{\mathrm{i}}$ is the relative abundance of the $i$ th species, $S$ is the number of species in the community, and Equation 2:

$$
E^{\prime}=\frac{S-\left(\sum_{h}^{K}\left|p_{i h}-p_{j h}\right|\right)}{S}
$$

where $S$ is the number of species in the community $h, p_{i h}$ is the relative abundance of a competing species $i, p_{\mathrm{jh}}$ is the relative abundance of a competing species $j$, and $K$ is the maximum number of possible binary subtractions between competing species, following $\mathrm{K}=\mathrm{S}\left(\mathrm{S}^{-1}\right) / 2$ (Camargo, 1993). Species richness was considered as the number of species per sample.

Spearman's correlation and cluster analysis using Bray Curtis' Similarity Matrix were performed on Primer software with diversity, evenness, fish species abundance, pluviometric and water volume data. Spearman's rank correlation was performed to determine the relations between environmental (pluviometry and water volume) and biological (diversity, evenness and fish population parameters) variables. Data transformation was not necessary. Cluster analysis was used to verify the existence of patterns in species distribution throughout time. The Bray-Curtis index was used as similarity measure and groups were clustered using the unweighted pair-group average method (Sokal and Rohlf, 1980).

\section{Results}

\subsection{Ichthyofauna composition}

A total of 889 individuals belonging to 11 species, 10 genera, nine families and four orders were collected during the study period (Table 1).

Species richness varied among different months, from six (in June of 2006) to 10 species (in March and August of 2006). There was no significant correlation between species richness and precipitation rates $\left[\mathrm{r}_{S}=0.19 ; \mathrm{N}=6\right.$; $\mathrm{p}=0.71]$, as well as between species richness and water volume in the reservoir $\left[\mathrm{r}_{S}=-0.32 ; \mathrm{N}=6 ; \mathrm{p}=0.53\right]$.

The abundance of different species showed seasonal variation. A negative significant correlation was observed between number of individuals and precipitation $\left[\mathrm{r}_{S}=-0.81\right.$; $\mathrm{N}=6 ; \mathrm{p}<0.05]$. This result indicates that during the rainy season, the number of caught individuals decreased (78 in March/2006 and 109 June/2006) (Table 2).

\begin{tabular}{|c|c|}
\hline Taxon & Common name \\
\hline \multicolumn{2}{|l|}{ Characiformes } \\
\hline \multicolumn{2}{|l|}{ Anostomidae } \\
\hline Leporinus cf. piau (Fowler, 1941) & Piau \\
\hline \multicolumn{2}{|l|}{ Characidae } \\
\hline Astyanax bimaculatus (Linnaeus, 1758) & Piaba do rabo amarelo \\
\hline Astyanax fasciatus (Cuvier, 1819) & Piaba do rabo vermelho \\
\hline \multicolumn{2}{|l|}{ Crenuchidae } \\
\hline Characidium bimaculatum (Fowler, 1941) & Canivete \\
\hline \multicolumn{2}{|l|}{ Curimatidae } \\
\hline Steindachnerina notonota (Miranda-Ribeiro, 1937) & Sagüiru, Saburú \\
\hline \multicolumn{2}{|l|}{ Erythrinidae } \\
\hline Hoplias malabaricus (Bloch, 1794 ) & Traíra \\
\hline \multicolumn{2}{|l|}{ Prochilodontidae } \\
\hline Prochilodus brevis (Steindachner, 1875) & Curimatã \\
\hline \multicolumn{2}{|l|}{ Cyprinidontiformes } \\
\hline \multicolumn{2}{|l|}{ Poeciliidae } \\
\hline Poecilia vivipara (Bloch \& Schneider, 1801) & Guarú, Barrigudinho \\
\hline \multicolumn{2}{|l|}{ Perciformes } \\
\hline \multicolumn{2}{|l|}{ Cichlidae } \\
\hline Cichlasoma orientale (Swainson, 1839) & Cará \\
\hline Oreochromis niloticus (Linnaeus, 1978) & Tilápia nilótica \\
\hline \multicolumn{2}{|l|}{ Siluriformes } \\
\hline \multicolumn{2}{|l|}{ Loricariidae } \\
\hline Hypostomus sp. & Cascudinho, Chupa pedra \\
\hline
\end{tabular}

Table 1. Fish species recorded in Taperoá II reservoir during the study period, with their respective regional common names. 
Table 2. Absolute abundance of the fish species in Taperoá II reservoir during the study period.

\begin{tabular}{|c|c|c|c|c|c|c|c|c|}
\hline \multirow[t]{2}{*}{ Species } & \multicolumn{2}{|c|}{$\begin{array}{c}\text { Dry } \\
\text { season/2005 }\end{array}$} & \multicolumn{2}{|c|}{$\begin{array}{c}\text { Rainy } \\
\text { season/2006 }\end{array}$} & \multicolumn{2}{|c|}{$\begin{array}{c}\text { Dry } \\
\text { season/2005 }\end{array}$} & \multirow[t]{2}{*}{ Total } & \multirow{2}{*}{$\begin{array}{c}\text { Relative } \\
\text { abundance } \\
(\%)\end{array}$} \\
\hline & Oct./05 & Dec./05 & Mar./06 & June/06 & Aug./06 & Oct./06 & & \\
\hline Leporinus cf. piau & 5 & 6 & 4 & - & 28 & 46 & 89 & 22.6 \\
\hline Astyanax bimaculatus & 72 & 10 & 8 & 25 & 48 & 37 & 200 & 16.0 \\
\hline Astyanax fasciatus & 17 & 6 & 12 & - & 79 & 28 & 142 & 6.5 \\
\hline Characidium bimaculatum & 7 & - & 4 & 41 & 34 & 36 & 122 & 13.8 \\
\hline Steindachnerina notonota & 45 & 43 & 26 & 1 & 3 & 2 & 120 & 13.7 \\
\hline Hoplias malabaricus & 6 & 23 & 9 & 7 & 7 & 7 & 59 & 13.5 \\
\hline Prochilodus brevis & - & - & 1 & - & - & - & 1 & 10.0 \\
\hline Poecilia vivipara & 7 & 36 & 10 & 15 & 45 & 10 & 123 & 0.4 \\
\hline Cichlassoma orientale & - & 1 & - & - & 1 & 2 & 4 & 2.9 \\
\hline Oreochromis niloticus & - & 1 & 3 & 20 & 1 & 1 & 26 & 0.3 \\
\hline Hypostomus sp. & - & 1 & 1 & - & 1 & - & 3 & 0.1 \\
\hline Total & 7 & 9 & 10 & 6 & 10 & 9 & 889 & \\
\hline
\end{tabular}

\subsection{Abundance, dominance and constancy}

According to the Constancy Index, eight species were considered constant (Astyanax bimaculatus, Astyanax fasciatus, Hoplias malabaricus, Poecilia vivipara, Characidium bimaculatum, Steindachnerina notonota, Leporinus piau, Oreochromis niloticus), two accessory (Cichlassoma orientale, Hypostomus sp.) and one accidental (Prochilodus brevis).

Hoplias malabaricus showed higher abundance during the period with lower water volume (dry season of 2005). Astyanax bimaculatus and A. fasciatus were more abundant during the dry seasons. These species, which were the most abundant in the reservoir (38.5\% dominance degree), belong to the Characidae, which comprised $18.2 \%$ of all caught species (Figure 3 ).

\subsection{Assemblage parameters and similarity}

\subsubsection{Diversity and evenness indices}

The fish assemblage of Taperoá II Reservoir showed a mean Shannon diversity index of 2.4 bits/ind. There were no significant temporal variations in the diversity index throughout the study period. Also, no significant correlations between diversity index and precipitation rate, and between diversity index and water volume of the reservoir were observed. Nevertheless, the highest diversity value was recorded in March of 2006 (H' = 2.8 bits/ ind), which coincided with a precipitation peak, and with the highest species richness (10 species). This was probably a consequence of greater food availability caused by a higher input of alloctone matter during this rainy period (Figure 4), favouring the presence of more diverse food, which was already observed in a previous work (Montenegro, 2007). The lowest diversity value was recorded in October of 2005 (dry period, H' = 2.1 bits/ind), coinciding with the low species richness value (7 species). In this sample, Cichlassoma orientale, Oreochromis niloticus, Hypostomus sp. and Prochilodus brevis were not collected.

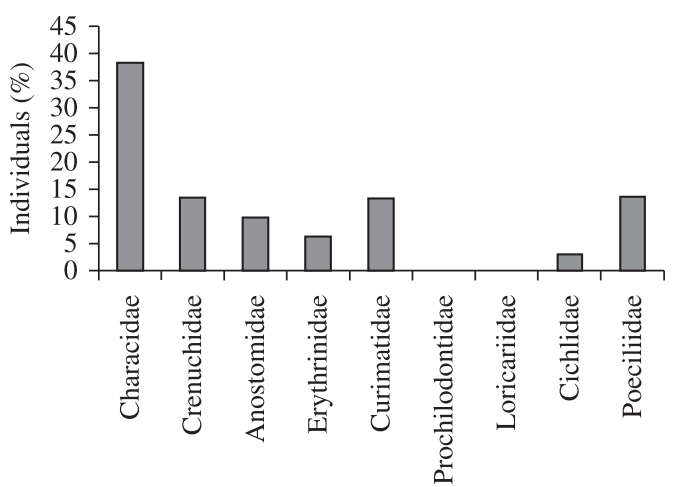

Figure 3. Relative abundance of the fish families of Taperoá II Reservoir during the study period.

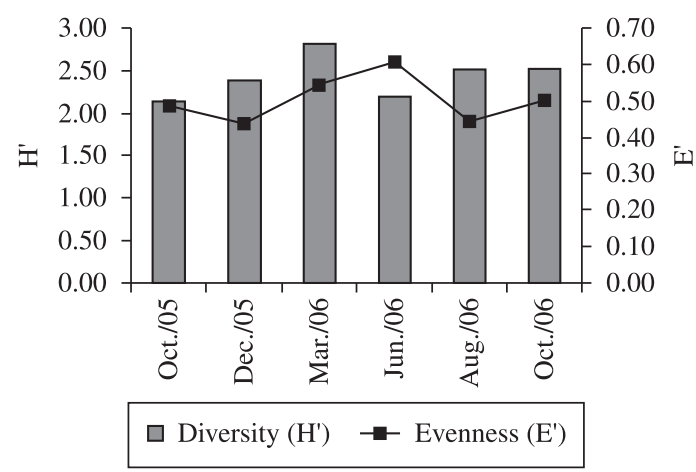

Figure 4. Temporal variation of species diversity (Shannon's index) and evenness (Camargo's index) of fish community from Taperoá II Reservoir during the study period.

Similarly to diversity, the evenness index values did not show significant variations throughout the study period. Evenness values did not correlate with the precipitation $\left[\mathrm{r}_{S}=0.4 ; \mathrm{N}=6 ; \mathrm{p}=0.4\right]$ or water volume $\left[\mathrm{r}_{S}=0.4 ; \mathrm{N}=6\right.$; $\mathrm{p}=0.3]$. The highest homogeneity of species abundance 


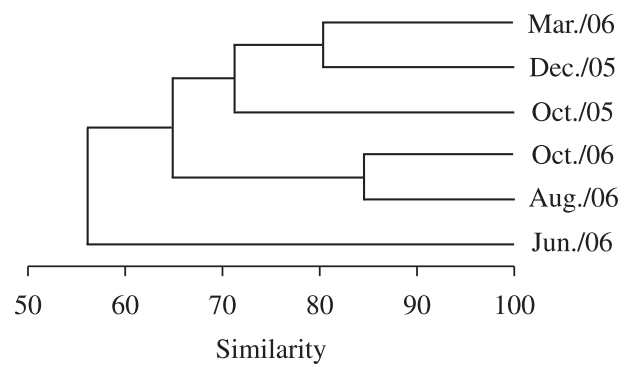

Figure 5. Cluster analysis based on a Bray-Curtis similarity matrix between samples for the Reservoir Taperoá II fish community.

was registered in June of 2006 (rainy period, E' $=0.6$ ), and the lowest in December of 2005 (dry period, E' $=0.4$ ). Thus, in general, evenness values were considered low, which means that some species showed a higher abundance than others (Figure 4).

\subsubsection{Similarity analysis}

Cluster analysis distinguished three groups by sampling period (Figure 5). The lowest similarity value was obtained between June of 2006 and the remaining months. This month showed the lowest species richness, along with low diversity and high evenness indices. It represented the sum of precipitation during the rainy season, being the month with the highest water accumulation and an overflow.

Cluster analysis showed resemblances in the ichthyofauna between August and October of 2006. These months presented similarities in biodiversity and in the frequency of constant and accessory species. Further, on both months, the reservoir presented a great water volume, albeit not overflowing (Figure 2). The last cluster groups were formed by the months of March of 2006 and December of 2005, and by these two months together with October of 2005. Although these three months presented relatively different features, they were characterised by low water volume.

\section{Discussion}

In the present study, an ecological succession was observed between the species Leporinus piau and Steindachnerina notonota. The former species is omnivorous, and latter is detritivorous, both species feed on the reservoir's substrate that observes alternation may be a strategy to avoid competition.

According to Welcomme (1979), the relative abundance of predatory fish usually increases during the dry season due to higher grazing rates. In the present study, the predator H. malabaricus showed a higher abundance during the dry period. It could also be due to the greater ecological densities in the community, given by the greater abundance of the organisms during the low water period volume. It is important to differentiate between total density (number by total space unit) and specific, or ecological density (number by space unit or habitat), which is the area or available volume that can be colonised by a population (Odum, 2001). A decrease in the dam's water volume is followed by a corresponding increase in ecological density, which is reflected in both an increase in predation risk and an increase in the concentration of individuals per space unit, increasing competition for food resources and accelerating environmental disturbances, such as eutrophisation processes (Crispim et al., 2000), which favours some species, but at the cost of negatively affecting others. This was illustrated for Characidium bimaculatum, which was not observed during December of 2005 (dry period). This species feeds on aquatic insects (Montenegro, 2007) and is likely to be more sensitive to the chemical and physical disturbances common during the dry period.

Agostinho et al. (2007) stated that almost $85 \%$ of the Brazilian reservoirs sustain a total richness of less than 40 fish species. Approximately half of these water bodies sustain a richness of 20 to 40 species, with a mean of 30 species per reservoir.

The variation in species abundance between seasons may also be related to the use of diverse environmental resources, which allows the species to coexist. A good example of this is the coexistence between A. bimaculatus and A. fasciatus in the reservoir, both abundant during the dry seasons. The abundance and coexistence of these two species was also observed by Hoffmann et al. (2005), Galetti Junior et al. (1990), Agostinho et al. (1997a,1997b), Schifino et al. (2004) and Teixeira et al. (2005).

According to Agostinho et al. (2007), the number of dominant species in Brazilian reservoirs is low, varying between two and 22, and with a mean of six species in each assembly. These researchers also stated that the dominance of few species is a recurrent phenomenon in reservoirs, because flexible, opportunistic species adapt better to new environments and can numerically surpass the others. In such reservoirs, approximately $25 \%$ of the species contribute with more than 80 of the total abundance.

The relevant participation of the Characidae (Characiformes), is a result of their wide distribution in freshwater environments. This family includes the majority of continental waters species of Brazil (Britski, 1972), where there is a predominance of small species and/or fishes that can complete their life cycle in lentic environments, as stated by Araújo and Santos (2001).

Species such as A. bimaculatus have flexible feeding habits and are able to reproduce in several types of habitats (Bennemann et al., 2000). These characteristics, along with their common frequency throughout the study may explain their abundance in Taperoá II reservoir. Agostinho et al. (2007) stated that A. altiparanae (Garutti and Britski, 2000) (same genus) is the most frequent species in Brazilian reservoirs (44\%). These authors also emphasized the high frequency of $A$. fasciatus.

Seasonal variations in the abundance of species may be related to differences in resource utilisation, which allow coexistence. Astyanax bimaculatus and A. fasciatus were more abundant during the dry periods, an association possibly related to their ability to tolerate the inherent environmental conditions of this period. These species belong to the family Characidae which comprised $18.18 \%$ of all 
individuals collected in the present study, and, according to the constancy index, were also the most abundant $(38.47 \%$ of degree of dominance). According to Luiz et al. (2003), A. scabripinnis paranae (Eigenmann, 1927) was dominant in Alagados Reservoir (Paraná, Brazil), accounting for nearly $86 \%$ of all collected individuals. The second most abundant species in this reservoir, Geophagus brasiliensis, accounted for only $8 \%$.

Of the eleven taxa recorded throughout the study, most were categorised as constant, with Cichlasoma orientale and Hypostomus sp. categorised as accessory and Prochilodus brevis as accidental. Different results were observed by Galetti et al. (1990) in lakes from São Paulo (Brazil), where few constant species were registered. Bertoletti et al. (1989) recorded a total of 69 species in Uruguay River (Santa Catarina, Brazil), with only 24 species being considered constant.

In Taperoá II Reservoir, particularly, the high abundance of constant species may reflect its good conservation state. Vieira (2002) disagrees that such characteristic may be reflective of the conservation state of an environment. However, in this study, the author compared species from non-impacted environments with small samples of impacted environments.

The presence of constant species in these environments subject to major intermittent hydrological fluctuations illustrate the survivorship potential of these species during all ontogenetic stages, regardless of seasonal variations in feeding resources (Montenegro, 2007). According to Lemes and Garutti (2002), the constancy of some species reflects their biological ability to explore different environmental resources at each ontogenetic stage.

It is important to consider that Taperoá II Reservoir is located in one of the driest regions of Brazil $(300 \mathrm{~mm} /$ year), with drastic variations in water volume along its hydrological cycle. This dynamic environment forces the organisms to develop different abilities to cope with them, such as dormant stages to support uninhabitable conditions. Among species of the study area, individuals of the trahira Hoplias malabaricus bury themselves in the soft substrate during adverse dry periods (personal observation).Barbiere and Kronemberg (1994) stated that during the rainy season, there is an increase in the diversity of microhabitats. Higher water levels reach the marginal vegetation, which provides shelter to organisms, more complex environments and food resources not available during the dry period.

The presence of water in the environment, even if in small quantities, is a determinant factor for the promotion of higher diversity values. Odum (2001) proposes that the diversity tends to decrease with higher stress or alterations in the environmental dynamics. In 1999 and 2003, this reservoir became completely dry, forcing fish species to recolonize the environment. This may explain its low fish species richness of the reservoir.

Evenness of Taperoá II fish species was considered low, the findings of Agostinho et al. (2007) in Brazilian reservoirs (Samuel reservoir, Amazon basin; Tucuruí reservoir, Tocantins river basin; Lajes, Paraíba do Sul river) support this.

Given the results of the present study, all initial hypotheses were rejected. The first hypothesis was accepted since the observed fish diversity was considered low, the second hypothesis was partially rejected because statistics do not found significant differences, but some species changed both diversity and abundance, along the sazonal period, the third hypothesis was also accepted because two species (A. bimaculatus e A. fasciatus) were dominant throughout the study period.

Acknowledgements - We thank PELD/Caatinga - CNPq, for financially supporting the project and CAPES for providing a Master's degree grant to Ana Karla Araujo Montenegro.

\section{References}

Agência Executiva de Gestão das Águas do Estado da Paraíba AESA. Available from: <http://www2.aesa.pb.gov.br/meteoro/ chuvas.shtml>. Access in: 03 mar. 2007.

AGOSTINHO, AA., BINI, LM. and GOMES, LC., 1997a. Ecologia de comunidades de peixes da área de influência do reservatório de Segredo. In AGOSTINHO, AA. and GOMES, LC. (Eds.). Reservatório de Segredo: bases ecológicas para o manejo. Maringá: Eduem. 386 p.

AGOSTINHO, AA., GOMES, LC., and PELICICE, FM., 2007. Ecologia e manejo de recursos pesqueiros em reservatórios do Brasil. Maringá: Eduem. 501 p.

AGOSTINHO, AA., JÚLIO-JUNIOR, HF., GOMES, LC., BINI, LM. and AGOSTINHO, CS., 1997b. Composição, abundância e distribuição espaço-temporal da ictiofauna. In VAZZOLER, AEAM., AGOSTINHO, AA. and HAHN, NS. (Eds.). A planície de inundação do Alto Rio Paraná: aspectos físicos, biológicos e socioeconômicos. Maringá: Eduem. 386 p.

ARAUJO, FG. and SANTOS, LN., 2001. Distribution os fish assemblages in Lajes reservoir, Rio de Janeiro, Brazil. Brazilian Journal of Biology, vol. 61, no. 4, p. 563-576. http://dx.doi. org/10.1590/S1519-69842001000400006

BARBIERE, EB. and KRONEMBERG, DMP., 1994. Climatologia do litoral sul-sudeste do Estado do Rio de Janeiro. Cadernos de Geociências, vol. 12, p. 57-73.

BENNEMANN, ST., GEALH, AM., ORSI, ML. and SOUZA, LM., 2000. Ocorrência e ecologia trófica de quatro espécies de Astyanax (Characidae) em diferentes rios da bacia do rio Tibagi, Paraná, Brasil. Iheringia, Série Zoologia, vol. 95, no. 3, p. 247-254.

BERTOLETTI, JJ., LUCENA, CAS., LUCENA, ZMS., MALABARBA, LR. and REIS, RE., 1989. Ictiofauna do rio Uruguai Superior entre os municípios de Aratiba e Esmeralda, Rio Grande do Sul, Brasil. Comunicação Museu Ciências, PUCRS, Série Zoologia, vol. 48, p. 3-42.

BRITSKI, HA., 1972. Peixes de água doce do Estado de São Paulo - Sistemática. In: COMISSÃO INTERNACIONAL DA BACIA PARANÁ-URUGUAI. Poluição e Piscicultura. São Paulo: Faculdade de Saúde Pública da USP. p. 79-108.

BRITSKI, HA., SATO, Y. and ROSA, ABS., 1988. Manual de identificação de peixes da região de Três Marias. Brasília: CODEVASF. 115 p. 
CAMARGO, JA., 1973. Must dominance increase with the number of subordinate species in competitive interactions? Journal of Theoretical Biology, vol. 161, no. 4, p. 537-542.

DAJOZ, R., 1973. Ecologia Geral. São Paulo: EDUSP. 474 p.

FOWLER, HW., 1954. Os peixes de água doce do Brasil. Arquivos de Zoologia do Estado de São Paulo, vol. 9, no. 4, p. 400.

GALETTI-JUNIOR, PM., ESTEVES, KE., LIMA, NRW., MESTRINER, CA., CAVALLINI, MM., CESAR, ACG. and MIYAZAWA, CS., 1990. Aspectos comparativos da ictiofauna de duas lagoas marginais do rio Mogi-Guaçu (Alto Paraná Estação ecológica do Jataí, SP). Acta Limnologica Brasiliense, vol. 3 , p. $865-885$.

HOFFMANN, AC., ORSI, ML. and SHIBATTA, OA., 2005. Diversidade de peixes do reservatório da UHE Escola Engenharia Mackenzie (Capivara), Rio Paranapanema, bacia do alto Paraná, Brasil, e a importância dos grandes tributários na sua manutenção. Iheringia, Série Zoologia, vol. 95, no. 3, p. 319-325.

KENNEY, AJ. and KREBS, CJ., 2000. Programs for Ecological Methodology. Vancouver: University of British Columbia.

LEMES, EM. and GARUTTI, V., 2002. Ecologia da ictiofauna de um córrego de cabeceira da Bacia do Alto Rio Paraná, Brasil. Iheringia, Série Zoologia, vol. 92, no. 3, p. 69-78.

LUIZ, EA., GOMES, LC., AGOSTINHO, AA. and BULLA, CK., 2003. Influência dos processos locais e regionais nas assembléias de peixes em reservatórios do Estado do Paraná, Brasil. Acta Scientiarum: Biological Sciences, vol. 25, no. 1, p. 107-114.

McNAUGHTON, MC., 1968. Structure and function in California grassland. Ecology, vol. 49, p. 962-972. http://dx.doi. org/10.2307/1936547

MONTENEGRO, AKA., 2007. Bioecologia da ictiofauna do açude Taperoá II, semi-árido paraibano, Brasil. João Pessoa: Universidade Federal da Paraíba. Dissertação de Mestrado.

ODUM, EP., 2001. Fundamentos em Ecologia. Lisboa: Fundação Calouste Gulbenkian. 929 p.

Paraíba (Estado). Secretaria Extraordinária do Meio Ambiente, dos Recursos Hídricos e Minerais. Superintendência de Desenvolvimento do Meio Ambiente - SUDEMA, 1997. Zoneamento Ecológico
- Econômico do Estado da Paraíba: Região do Cariri Ocidental - Estudos Hidrológicos. João Pessoa: SUDEMA. 58 p.

PINTO-COELHO, RM., 2000. Fundamentos em Ecologia. Porto Alegre: Médica, $252 \mathrm{p}$.

ROSA, RS., MENEZES, NA., BRITSKI, HA., COSTA, WJEM. and GROTH, F., 2003. Diversidade, padrões de distribuição e conservação dos peixes da caatinga. In LEAL, IR., TABARELLI, M. and SILVA, JMC. (Eds.). Ecologia e Conservação da Caatinga, Recife: Editora Universitária da Universidade Federal de Pernambuco.

SANTOS, ACA., 2005. Ecologia alimentar do Molé Trachelyipterus galeatus (Linnaeus, 1766) (Siluriformes, Auchenipteridae), em trechos interiores dos rios Santo Antônio e São José (Chapada Diamantina, Bahia). Sitientibus Série Ciências Biológicas, vol. 5, no. 2, p. 93-98.

SCHIFINO, LC., FIALHO, CB. and VERANI, JR., 2004. Fish community composition, seasonality and abundance in Fortaleza lagoon, Cidreira. Brazilian Archives of Biology and Technology. v. 47, n. 5 , p. $755-763.2004$.

SOKAL, RR. and ROHLF, FJ., 1980. Biometry: The principles and practice in biological research. New York: W. H. Freeman.

TEIXEIRA, TP., PINTO, BCT., TERRA, BF., ESTILIANO, EO., GRACIA, D. and ARAUJO, FG., 2005. Diversidade das assembléias de peixes nas quatro unidades geográficas do rio Paraíba do Sul. Iheringia, Série Zoologia, vol. 95, no. 4, p. 347-357.

VARI, RP., 1991. Systematics of the neotropical Characiform genus Steindachnerina Fowler (Pisces: Ostariophysi). Smithonian Contributions to Zoology, vol. 507, 118 p.

VIEIRA, I., 2002. Freqüência, constância, riqueza e similaridade da bacia do rio Curuá-Una, Amazônia. Revista Brasileira de Zoociências, vol. 2, no. 2, p. 51-76.

WELCOMME, RL., 1979. Fisheries ecology of floodplain rivers. London: Longman. 317 p.

WOOTTON, RJ., 1990. Introduction: tactics and strategies in fish reproduction. In: POTTS, GW. and WOOTTON, RJ. (Eds.). Fish Reproduction: strategies and tactics. London: Academic Press, p. 1-12. 